\title{
Kampanye Sosial Gerakan Menutup Aurat di Bekasi
}

\author{
Ratih Firdiyah dan Winda Primasari \\ Program Studi Ilmu Komunikasi Universitas Islam “45” Bekasi \\ Email: wind.prims@gmail.com
}

\begin{abstract}
Gerakan Menutup Aurat (GEMAR)² Bekasi was a social campaign conducted by twenty two muslim communities in Bekasi to raise the awareness of young muslim women to wear hijab or muslim clothing which followed the Islamic rule or syari'i in the early 2017. This study investigated the social campaign used by GEMAR in the perspective of campaign model of five functional stages development. The research method used in this study is a qualitative descriptive method in which in-depth interviews were applied to collect data. The findings show that by following five functional stages development, GEMAR was able to revive the awareness of muslim women in Bekasi to wear Islamic clothing or syari'i.
\end{abstract}

Keywords: social campaign, young muslim movement, GEMAR Bekasi, Islamic clothing, five functional stages development.

\begin{abstract}
Abstrak
Gerakan Menutup Aurat (Gemar) Bekasi adalah kampanye sosial yang dijalankan oleh 22 komunitas muslim di Bekasi yang membangkitkan kesadaran perempuan muda muslim untuk memakai hijab atau busana muslimah mengikuti aturan Islam atau syar I pada awal 2017. Penelitian ini meneliti kampanye sosial yang digunakan oleh GEMAR dalam perspektif model kampanye lima tahap fungsi pembangunan. Metode penelitian yang digunakan dalam penelitian ini adalah metode penelitian kualitatif deskriptif melalui wawancara mendalam yang diterapkan dalam proses pengumpulan datanya. Temuan penelitian menunjukkan bahwa dengan mengikuti lima tahap fungsional pembangunan, GEMAR dapat membangkitkan kesadaran perempuan muslim di Bekasi untuk memakai busana muslimah atau syar'i
\end{abstract}

Kata Kunci: Kampanye sosial, Gerakan Pemuda Muslim, GEMAR Bekasi, Pakaian Islam, Lima Fungsi perkembangan 


\section{Pendahuluan}

Pemuda dikenal dengan istilah "agent of changes" atau agen perubahan, seperti dalam UU Negara Republik Indonesia No.40 tahun 2009 tentang Kepemudaan pasal 16 mengenai peran pemuda yaitu: "Pemuda berperan aktif sebagai kekuatan moral, kontrol sosial, dan agen perubahan dalam segala aspek pembangunan nasional." Pemuda Bekasi merupakan generasi aktif, kreatif, inovatif dan dinamis. Aktivitas pemuda Bekasi dapat terlihat dari banyaknya dan beragamnya komunitas yang ada di Bekasi. Hal tersebut terlihat pada acara Hari Komunitas Bekasi (HAKABE) di Grand Galaxy Park Mall Bekasi. Acara ini dihadiri oleh berbagai komunitas sebanyak 40 komunitas (Firmansyah, 2016). Komunitas-komunitas inipun bersinergi dalam mengadakan kampanye sosial, yakni Gerakan Menutup Aurat (GEMAR) Bekasi. GEMAR Bekasi diselenggarakan oleh dua puluh dua komunitas muda muslim Bekasi, (RWA/HIA, 2017).

Gerakan Menutup Aurat (GEMAR) Bekasi merupakan upaya penyadaran kepada perempuan muslim (muslimah) untuk menutup aurat berdasarkan ketentuan Al Qur'an. Selain itu, GEMAR juga merupakan upaya dalam melawan budaya asing dan meningkatkan nilai spiritual umat muslim di Bekasi. Apalagi saat ini gempuran berbagai media sosial dan internet telah banyak membuat umat muslim jauh dari nilai-nilai Islami. Lebih lanjut gerakan ini bertujuan untuk mengajak para muslimah di Bekasi agar memakai jilbab yang sesuai dengan ketentuan syar'i.

Sebenarnya Gerakan Menutup Aurat (GEMAR) adalah kampanye muslim yang digalakan secara nasional yang dipelopori oleh komunitas Peduli Jilbab. Komunitas ini terbentuk pada tahun 2012 untuk mengampanyekan penggunaan jilbab sesuai fungsi dan kriterianya atau jilbab syar'I (Awalina, 2015: 5). Namun tidak seperti kotakota lain, GEMAR Bekasi bukanlah bagian dari agenda komunitas Peduli Jilbab, melainkan direhat oleh pelbagai komunitas muda Bekasi yang tergabung dalam Sinergi Komunitas Bekasi (SKB) yaitu sebanyak 22 komunitas.

Tuti selaku ketua pelaksana GEMAR Bekasi 2017 mengatakan bahwa GEMAR Bekasi diadakan sebagai penyuluhan, ajakan atau sosialisasi kepada masyarakat Bekasi untuk menutup aurat. Ia melanjutkan, untuk mewujudkan hal tersebut akhirnya para komunitas memutuskan untuk mengadopsi kampanye GEMAR di Bekasi. Kampanye sosial GEMAR di Bekasi telah berjalan selama dua tahun yaitu tahun 2016 dan 2017. Rencananya kegiatan ini akan menjadi agenda tiap tahun kedepan. Tuti menambahkan bahwa ia berharap GEMAR Bekasi dapat berdampak positif bagi kehidupan sosial masyarakat muslim di Bekasi.

Kampanye sosial ini menarik untuk diteliti menggunakan model kampanye The Five Functional Development. Model kampanye digunakan untuk mengetahui strategi kampanye dari GEMAR Bekasi. Model ini dikembangkan oleh tim peneliti dan praktisi kampanye di Yale University AS pada awal tahun 1960an. Model ini dianggap paling popular dan banyak diterapkan di berbagai belahan dunia. Kepopuleran ini tidak terlepas dari fleksibilitas model untuk diterapkan. Fokus model ini ialah pada tahapan kegiatan kampanye yang meliputi lima tahap, yaitu tahap: identifikasi, legitimasi, partisipasi, penetrasi, dan distribusi, (Venus, 2004: 18-21).

Berdasarkan pemaparan tersebut maka tujuan penelitian ini untuk menganalisis tahapan kampanye sosial Gerakan Menutup Aurat (GEMAR) Bekasi dalam perspektif model kampanye Five Functional Stages Development. Rogers dan Storey (1987) mendefinisikan kampanye sebagai "serangkaian tindakan komunikasi yang terencana dengan tujuan menciptakan efek tertentu pada sejumlah besar khalayak yang dilakukan secara berkelanjutan pada kurun waktu tertentu (Venus, 2004: 7)

Apapun ragam dan tujuannya, menurut Pfau dan Parrot (1993) upaya perubahan yang dilakukan kampanye selalu terkait dengan aspek pengetahuna (knowledge), sikap (attitude) 
dan perilaku (behavioral). Ostergaard (2002) menyebut ketiga aspek tersebut dengan istilah "3A" yakni awareness, attitude, dan action. Ketiga aspek ini bersifat saling terkait dan merupakan sasaran pengaruh (target of influence) yang mesti dicapai secara bertahap agar satu kondisi perubahan dapat tercipta. (Venus, 2004: 10). Pertama, wareness.

Pada tahap pertama ini kegiatan kampanye biasanya diarahkanuntuk menciptakan perubahan pada tataran pengetahuan atau kognitif. Kedua, Attitude. Tahapan berikutnya diarahkan pada perubahan dalam ranah sikap atau attitude. Sasarannya adalah untuk memunculkan simpati, rasa suka, kepedulian atau keberpihakan khalayak pada isu-isu yang menjadi tema kampanye. Ketiga, behavioral. Ditunjukkan untuk mengubah perilaku khalayak secara konkret dan terukur. Tahap ini menghendaki adanya tindakan tertentu yang dilakukan oleh sasaran kampanye. Tindakan tersebut dapat bersifat 'sekali itu saja' atau berkelanjutan (terus-menerus).

Charles U. Larson (1992) membagi jenis kampanye ke dalam tiga kategori : (Venus, 2004: 11)

\section{Product-oriented campaigns}

Kampanye yang berorientasi pada produk umumnya terjadi dilingkungan bisnis. Istilah lainnya adalah commercial campaigns atau corporate campaign. Motivasi dasarnya adalah memperoleh keuntungan finansial.

\section{Candidate-oriented campaigns}

Kampanye yang berorientasi pada kandidat umumnya dimotivasi hasrat untuk meraih kekuasaan politik. Karena itu kampanye jenis ini disebut juga political campaigns (kampanye politik).

3. Ideologically or cause oriented campaigns

Jenis kampanye yang berorientasi pada tujuan-tujuan yang bersifat khusus dan seringkali berdimensi perubahan sosial. Karena itu kampanye jenis ini dalam istilah Kotler disebut sebagai social change campaigns, yakni kampanye yang ditunjukkan untuk menangani masalah- masalah sosial melalui perubahan sikap dan perilaku publik yang terkait.

Model ini dikembangkan oleh tim peneliti dan praktisi kampanye di Yale University As pada awal tahun 1960-an. Model ini dianggap paling popular dan banyak diterapkan di berbagai belahan dunia. Fokus model ini adalah pada tahapan kegiatan kampanye bukan pada proses pertukaran pesan antara campaigner dengan campaigenee. Tahapan kegiatan tersebut meliputi. (Venus, 2004: 18-21) :

1. Tahap Identifikasi

Tahap penciptaan identitas kampanye yang dapat dengan mudah dikenali oleh khalayak. Hal-hal yang umum digunakan sebagai identitas kampanye diantaranya, simbol, warna, lagu atau jingle, seragam dan slogan.

2. Tahap Legitimasi

Dalam kampanye politik, legitimasi diperoleh ketika seseorang telah masuk dalam daftar kandidat anggota legislatif, atau seseorang kandidat presiden memperoleh dukungan yang kuat dalam polling yang dilakukan lembaga independen. Pada kampanye produk, legitimasi seringkali ditunjukkan melalui testimoni atau pengakuan konsumen tentang keunggulan produk tertentu. Testimoni tersebut dapat diberikan oleh Public Figure.

3. Tahap Partisipasi

Tahap ini dalam prakteknya relatif sulit dibedakan dengan tahap legitimasi karena ketika seorang kandidat, produk atau gagasan mendapatkan mendapatkan legitimasi, pada saat yang sama dukungan yang bersifat partisipatif mengalir dari khalayak. Partisipasi ini bisa bersifat nyata (real) atau simbolik. Partisipasi nyata ditunjukkan oleh keterlibatan orang-orang dalam menyebarkan pamflet, brosur atau poster, menghadiri demonstrasi yang diselenggarakan sebuah lembaga swadaya masyarakat 
atau memberikan sumbangan untuk perjuangan partai. Sementara partisipasi simbolik bersifat tidak langsung, misalnya ketika seseorang menempelkan striker Partai Amanat Nasional di kaca belakangan mobil, memakai bungkus ban serep mobil dengan tulisan namaprosuk tertentu, atau sekedar mengenakan kaos partai tertentu yang dibagikan secra gratis.

4. Tahap Penetrasi

Pada tahap ini seorang kandidat, sebuah produk atau gagasan telah hadir dan mendapat tempat dihati masyarakat. Sebuah produk telah menguasai sekian persen dari pangsa pasar yang ada, atau sebuah kampanye yang ditunjukan untuk menentang kebijakan pemerintah mendapat liputan media massa secar luas dan mendapat tanggapan serius pemerintah dengan membuka dialog untuk mencari jalan keluar terbaik.

5. Tahap Distribusi

Bisa disebut juga sebagai tahap pembuktian. Pada tahap ini umumnya tujuan kampanye telah tercapai. Tinggal sekarang bagaimana mereka membuktikan janji-janji mereka saat kampanye. Janji kenaikan tarif tol akan disertai dengan peraikan kuaitas jalan dan pelayanan, atau janji membeli mobil tertentu akan disertai dengan jaminan garansi perbaikan selama satu tahun harus dibuktikan.

Littlejohn (2009: 57) menjelaskan bahwa fenomenologi merupakan cara yang digunakan manusia untuk memahami dunia melalui pengalaman langsung. Secara disiplin ilmu, fenomenologi mempelajari struktur pengalaman dan kesadaran. Secara harfiah, fenomenologi adalah studi yang mempelajari suatu fenomena, seperti penampakan, segala hal yang muncul dalam pengalaman kita, cara kita mengalami sesuatu dan makna yang kita miliki dalam pengalaman kita. (Kuswarno, 2009: 22).
Stanley Deetz menyimpulkan ada tiga prinsip dasar (asumsi) fenomenologi. Pertama, pengetahuan ditemukan secara langsung dalam pengalaman sadar. Kedua, makna benda terdiri atas kekuatan benda dalam kehidupan seseorang. Asumsi ketiga nahwa bahasa merupakan kesadaran makna, (Littlejohn, 2009: 57).

Alfred Schutz merupakan salah satu tokoh fenomenologi yang terkenal, bahkan dalam Kuswarno (2009: 17) mengatakan Alfred Schutz sebagai ahli teori fenomenologi yang paling menonjol. Dia yang membawa fenomenologi ke dalam ilmu sosial, membuat fenomenologi menjadi ciri khas bagi ilmu sosial hingga saat ini. Baginya tugas fenomenologi adalah menghubungkan antara pengetahuan ilmiah dengan pengalaman sehari-hari, dan dari kegiatan dimana pengalaman dan pengetahuan itu berasal. Dengan kata lain mendasarkan tindakan sosial pada pengalaman, makna dan kesadaran.

Inti pemikiran Schutz adalah bagaimana memahami tindakan sosial melalui penafsiran. Proses penafsiran dapat digunakan untuk memperjelas atau memeriksa makna yang sesungguhnya, sehingga dapat memberikan konsep kepekaan yang implisit. Schutz meletakkan hakikat manusia dalam pengalaman subjektif, terutama ketika mengambil tindakan dan mengambil sikap terhadap dunia kehidupan sehari-hari.

Menurut Schutz, makna subjektif bukan ada pada dunia privat, personal atau individual. Makna subjektif yang terbentuk dalam dunia sosial oleh aktor berupa sebuah "kesamaan" dan "kebersamaan" (common dan shared) di antara para aktor. Oleh karenanya sebuah makna subjektif disebut sebagai "intersubjektif".

Selain makna "intersubjektif", dunia sosial, menurut Schutz, harus dilihat secara historis. Sehingga Schutz menyimpulkan tindakan sosial adalah tindakan yang berorientasi pada perilaku atau orang lain pada masa lalu, sekarang dan akan datang. Schutz memaparkan bahwa tindakan adalah perilaku yang diarahkan untuk mewujudkan tujuan pada masa datang 
yang telah ditetapkan (determinate).

Proyek adalah sebuah makna yang rumit atau makna yang kontekstual. Oleh karenanya, untuk menggambarkan keseluruhan tindakan seseorang, perlu diberi fase. Dua fase yang diusulkan Schutz diberi nama tindakan in-orderto motive (Um-zu-Motiv), yang merujuk pada masa yang akan datang, dan tindakan becausemotive (Weil-Motiv) yang merujuk pada masa lalu.

Scott dan Lyman menjelaskan istilah motives lebih berkonotasi kajian pskologis, sedangkan sebagai sosiolog mereka mengusulkan istilah yang khas sosiologi yaitu : accounts. Scott dan Lyman menyebutkan terdapat dua tipe accounts, yaitu permasalahan (excuses) dan pembenaran (justifications). Tipe pertama adalah pengakuan atas tindakan yang buruk, salah atau tidak layak. Sedangkan tipe kedua adalah pengakuan tentang tanggung jawab penuh atas tindakan yang dipertanyakan. (Kuswarno, 2009: 109-111).

Pakaian adalah salah satu karunia yang diberikan Allah SWT kepada manusia. Manusia memerlukan pakaian sebagai bagian dari produk budaya, akan tetapi Islam memberikan pula ketentuan berkaitan dengan pakaian dimana pada dasarnya pakaian berfungsi untuk menutup aurat, (Takariawan dkk, 2003:68).

Hai anak Adam, sesungguhnya Kami telah menurunkan kepadamu pakaian untuk menutup auratmu dan pakaian indah untuk perhiasan. Dan pakaian takwa itulah yang paling baik. yang demikian itu adalah sebahagian dari tanda-tanda kekuasaan Allah, mudah-mudahan mereka selalu ingat. (Q.S. Al-A'raf (7): 26)

Ayat di atas menunjukkan bahwa bagi tiap muslimin diperintahkan untuk menutup auratnya. Aurat menurut etimologi adalah setiap sesuatu yang terlihat buruk. Adapun menurut terminologi, aurat ialah sebagian tubuh manusia yang wajib ditutupi dan diharamkan membuka dan melihat atau menyentuhnya, (Dewi, 2014: 1). Aurat harus ditutupi karena dapat menimbulkan madharat, memancing nafsu orang yang melihatnya, oleh karena itu harus dijaga sebaik- baiknya, (Dewi, 2014: 10).

Menurut istilah, dalam pandangan pakar hukum Islam, aurat adalah bagian dari tubuh manusia yang pada prinsipnya tidak boleh kelihatan, kecuali dalam keadaan darurat atau kebutuhan yang mendesak. Dalam Al-Quran telah disampaikan perintah untuk menutup aurat baik bagi laki-laki maupun perempuan, yakni dalam surah An-Nur ayat 30-31, (Takariawan dkk, 2003: 70-71).

Batasan aurat bagi perempuan diriwayatkan oleh At-Tirmizy mar'fuan bahwa: "Wanita itu adalah aurat, bila dia keluar rumah ,maka syetan menaikinya. Menurut At-Turmuzi hadist ini kedudukannya hasan sahih. Oleh para pendukung pendapat ini, tubuh wanita itu adalah aurat, termasuk wajah, tangan, kaki dan semua bagian tubuhnya. Adapun hadist lain yang diriwayatkan oleh Abu Daud yaitu : (Takariawan dkk, 2003: 121)

Rasullah Saw. Bersabda kepada Asma binti Abu Bakar: "Wahai Asma, sesungguhnya perempuan itu jika telah baligh (telah haidh) maka tidak boleh kelihatan darinya selain ini dan ini (beliau menunjuk ke wajjah dan telapak tangan beliau). (HR. Abud Daud) serta HR. Hadits shahih, diriwayatkan oleh imam Ahmad, Abu Dawud, at-Tirmidzi dan Ibnu Majah: Dan Rasulullah shallallahu 'alaihi wasallam juga bersabda: "Tidak diterima shalat seorang perempuan yang sudah haidh (maksudnya sudah baligh) kecuali dengan memakai khimar (kerudung yang menutup kepala)."

Ada beberapa istilah terkait pakaian muslimah yaitu jilbab, khimar, cadar, dan juga hijab. Hijab adalah tuntunan syariat yang diberikan kepada isteri-isteri Nabi, sesuai dalam surah Al-Ahzab ayat 53. Hijab bermakna penghalang atau tabir antara laki-laki dan perempuan untuk tidak saling melihat. Istilah hijab dikhususkan bagi para isteri-isteri Nabi dalam bergaul dengan laki-laki lain di dalam rumah, untuk membedakan isteri Nabi dengan perempuan lainnya, serta untuk menghormati keluarga Rasullah saw.

Akan tetapi, para perempuan sahabiyat 
Nabi tidak mendapatkan kewajiban sebagaimana para isteri Nabi. Pakaian muslimah tidak disebutkan sebagai hijab, melainkan libas, jilbab, atau khumur (khimar). Para perempuan Muslimah pada umumnya mendapatkan kewajiban menutup aurat dengan jilbab seperti pada surah Al-Ahzab ayat 59

Hai Nabi, katakanlah kepada isteriisterimu, anak-anak perempuanmu dan isteriisteri orang mukmin: "Hendaklah mereka mengulurkan jilbabnya ke seluruh tubuh mereka”. Yang demikian itu supaya mereka lebih mudah untuk dikenal, karena itu mereka tidak di ganggu. Dan Allah adalah Maha Pengampun lagi Maha Penyayang. (Q.S. Al-Ahzab (33): 59)

Jilbab adalah pakaian panjang yang dikenakan merangkapi pakaian perempuan dan tidak menutup wajahnya. Syrah Al-Ahzab ayat 59 menuntut kaum perempuan untuk mengulurkan jilbabnya ke tubuh mereka ketika keluar rumah sebagai identitas yang membedakan mereka dari perempuan budak, sehingga tidak ada yang mengganggu, (Takariawan dkk, 2003: 72).

Khimar yang dimaksud dalam firman Allah dalam surah An-Nur ayat 31 adalah penutup kepala, bukan penutup wajah. Dalam kitab Al'Mujam AL-Wasith disebutkan, 'Khimar adalah segala sesuatu yang menutup. Termasuk dalam jenis khimar adalah khimar perempuan, yaitu pakaian yang dikenakan kaum perempuan untuk menutup kepala mereka, (Takariawan dkk, 2003: 72).

Namun fenomena trend yang ada saat ini menyebut seluruh jibab/kerudung/penutup kepala perempuan sebagai hijab. Padahal itu semua tidak disebut sebagai hijab. Para perempuan muslimah di luar isteri Nabi tidak mendapatkan tuntunan hijab, melainkan untuk menggunakan khimar dan jilbab.

Dalam pasal 17 poin pertama, Peran aktif pemuda sebagai kekuatan moral diwujudkan salah satunya dengan: Memperkuat iman dan takwa serta ketahanan mental spiritual. Kemudian poin kedua, Peran Aktif pemuda sebagai kontrol sosial diwujudkan salah satunya dengan: Membangkitkan sikap kritis terhadap lingkungan dan penegakan hukum. Dari dua poin tersebut menunjukkan bahwa sebagai agen perubahan pemuda memiliki peran kepedulian terhadap lingkungan hidup dan masyarakat (sosial).

Selain itu, pemuda juga dikenal sebagai generasi M. Majalah TIME menyebut generasi ini sebagai: Multi-tasking Generation atau yang dikenal sebagai Generasi M. (Wallis, 2006). Dalam tulisannya Jean Twenge menyebut generasi ini sebagai generasi yang paling 'mengancam' sekaligus 'menarik', dalam hal ini majalah TIME menyebutnya sebagai "Baby Boomers".

Fenemona generasi millennium pada gilirannya telah melahirkan sebuah identitas baru pada umat muslim. Generasi $\mathrm{M}$ dalam dunia muslim juga disebut sebagai young millennial era Muslim. Sejalan dengan hal tersebut, dalam penelitian oleh Ogilvy Noor menyatakan bahwa generasi $\mathrm{M}$ merupakan segmen yang paling berpengaruh pada populasi Muslim. Ide-ide mereka merupakan pioneering dalam kehidupan sosial, (Janmohamed, 2016: 8).

Data kependudukan yang dirilis oleh Badan Pusat Stastistik (BPS) Kota Bekasi menunjukkan penduduk Bekasi terbanyak berada pada rentang usia antara 25-29 tahun (Population by Sexes and Age Group 2015). Jumlah pemuda Bekasi kelompok umur 25-29 tahun memiliki jumlah terbanyak, yaitu sebesar 295.052 jiwa. Jumlah pemuda (laki-laki) sebesar 146.452 dan jumlah pemudi (perempuan) sebesar 148.600. Data tersebut menunjukkan berdasarkan angka, Bekasi memiliki jumlah pemuda yang banyak. Dengan kata lain Bekasi akan terus mengalami perubahan kedepannya karena mempunyai jumlah agen perubahan (agent of changes) yang cukup banyak.

\section{Metode Penelitian}

Deskriptif kualitatif merupakan metode yang digunakan dalam penelitian ini, Objek penelitian ini adalah Kampanye Sosial GEMAR Bekasi, maka populasi penelitian ini adalah seluruh kegiatan, anggota, arsip, serta dokumen 
terkait aktivitas kampanye sosial Gerakan Menutup Aurat (GEMAR) Bekasi. Teknik sampling dalam penelitian ini menggunakan sampling snowball. Wawancara mendalam dilakukan untuk mengumpulkan data dengan analisis yang digunakan ialah analisis Miles Huberman.

Adapun wawancara dilakukan dengan sejumlah informan. Key informan dalam penelitian ini yaitu; 1). Tuti Alawiyah (Awi) sebagai Humas Pusat Peduli Jilbab, 2). AP dan KN sebagai peserta kegiatan GEMAR Bekasi 2017. Sedangkan informan pokok dalam penelitian ini adalah; 1). Tuti Susanti (Tuti) sebagai Ketua pelaksana GEMAR Bekasi 2017 serta perwakilan dari Sinergi Komunitas Bekasi (SKB), 2). Dita Asriani sebagai panitia relawan GEMAR Bekasi 2017. 3). Rahayu Purwatiningsih sebagai perwakilan dari Forum Silahturahi Lembaga Dakwah Kampus (FSLDK) Bekasi.

\section{Hasil dan Pembahasan Gambaran Umum GEMAR Nasional}

Gerakan Menutup Aurat (GEMAR) digagas oleh ustad sekaligus penulis buku best seller Herry Nurdi. Herry mengatakan gerakan aksi ini diawali dari keprihatinan bersama atas gejala budaya Valentine's day di Indonesia. Sebab menurutnya saat ini, budaya peringatan Valentine's day justru dimanfaatkan sebagai pintu perzinahan. Misalnya, terkait kasus pembagian kondom dan coklat dalam bingkisan Valentine's day di minimarket Bandung. (Tim, 2012).

Menurut Ustad Ahmad Yani, anggota Ikatan Dai Indonesia (Ikadi), perayaan Valentine's day di masa sekarang ini mengalami pergeseran. Jika di masa Romawi, sangat terkait erat dengan dunia para dewa dan mitologi sesat, kemudian di masa Kristen dijadikan bagian dari simbol perayaan hari agama, maka pada masa sekarang ini identik dengan pergaulan bebas. Mulai dari yang paling sederhana seperti pesta, kencan, bertukar hadiah hingga praktek zina secara legal. Semua mengatasnamakan cinta kasih, (Yani, 2014).
Dalam semangat hari Valentine itu, ada semacam kepercayaan bahwa melakukan maksiat dan larangan-larangan agama seperti berpacaran, bergandeng tangan, berpelukan, berciuman, bahkan hubungan seksual di luar nikah di kalangan sesama remaja itu menjadi boleh. Alasannya, semua itu adalah ungkapan rasa kasih sayang. Padahal mendekati zina saja haram, apalagi melakukannya. Allah SWT berfirman dalam surah Al Isro': 32- "Dan janganlah kamu mendekati zina; sesungguhnya zina itu adalah suatu perbuatan yang keji. Dan suatu jalan yang buruk." (Q.S. Al Isro (17) Ayat 32)

Hal itulah yang menjadi alasan pemilihan bulan Februari sebagai hari pelaksanaan kampanye Gerakan Menutup Aurat. Salah satu pesan lainnya yang ingin disampaikan melalui gerakan ini ialah mengajak para muslim dan muslimah untuk menjaga aurat mereka. Lebih jauh dengan menjaga aurat juga memiliki makna pembatas pergaulan antara laki-laki dan perempuan. Sehingga dapat membatasi pergaulan bebas yang marak terjadi.

Mulanya kampanye Gerakan Menutup Aurat diprakarsai oleh Herry Nurdi dan Teachers Working Group (TWG) sejak sekitar tahun 2004. Kemudian dalam perkembangannya Gerakan Menutup Aurat (GEMAR) mulai rutin dikoordinir oleh komunitas Peduli Jilbab. Peduli Jilbab membuka 'lelang kebaikan' kepada pelbagai komunitas yang ada di Jakarta dan sekitarnya untuk bisa bergabung merehat kegiatan ini. Akhirnya di tahun 2016 adalah kegiatan GEMAR pertama yang terbesar. Acara tersebut dihadiri oleh 2000 orang (dari pelbagai komunitas) yang berkumpul di bundaran $\mathrm{HI}$ Jakarta.

\section{Komunitas Peduli Jilbab}

Peduli Jilbab resmi dibentuk pada 19 Mei 2012. Komunitas ini dipelopori oleh Amalia Dian Ramadhani mulai merintis komunitas ini sejak 4 Mei 2011 saat mengikuti FIM (Forum Indonesia Muda) karena tergerak dengan keadaan muslimah yang ingi berjilbab syar'i 
namun terhalang oleh faktor dana atau ekonomi. Nama komunitas Peduli Jilbab diambil dari salah satu program rohis Amalia saat menempuh pendidikan di SMA N 5 Depok. Amalia menafsirkan nama Peduli Jilbab berdasarkan hadist yang menginspirasinya yang berbunyi: "Sebaik-baik manusia adalah yang paling bermanfaat bagi orang lain." (H.R. Muslim)

Organisasi ini memiliki rangkaian program kampanye bernama Yuk Berjilbab Syar'i untuk mengajak muslimah memakai jilbab sesuai kriteria syar'i. Kampanye tersebut dilakukan melalui berbagai media komunikasi agar visinya untuk mengembalikan jilbab sesuai fungsi dan kriterianya terpenuhi (Awalina, 2015: 2).

Dalam mengembangkan organisasinya Peduli Jilbab gencar melakukan komunikasi di media sosial seperti, twitter, facebook, dan instagram. Peduli Jilbab juga meminta bantuan retweet akun twitternya@pedulijilbab kepada akun terkenal atau jejaring komunitas muslim lainnya untuk membuat Peduli Jilbab semakin berkembang. Seperti@felixsiauw,@asmanadia dan@salimafillah untuk mempublikasikan adanya komunitas tersebut. Berkat 'Retweet' dari akun-akun tersebut jugalah awal @pedulijilbab memiliki follower yang terus bertambah, (Lestari, 2014).

Peduli Jilbab memiliki empat divisi. Keempat divisi ini dibentuk agar Peduli Jilbab mampu mengelola komunitas secara profesional. Divisi-divisi tersebut ialah Jilbab Share, Jilbab Care, Jilbab Wear dan Tim Kreatif.

\section{Profil Sinergi Komunitas Bekasi (SKB)}

Sinergi Komunitas Bekasi (SKB) merupakan wadah sinergi persaudaraan antar komunitas muslim di Bekasi. Sinergi Komunitas Bekasi berdiri sejak 2012, namun baru diresmikan melalui Musyawarah Besar pada tahun 2015 di ruang Aula Masjid Al-Azhar, Jakasampurna. Sekitar 13 komunitas hadir dari berbagai disiplin program yang berbeda, namun memiliki kepedulian yang sama untuk membangun masyarakat Bekasi yang berketuhanan, (MGI,
2015).

Sejak tahun 2015 hingga 2017 SKB telah bergantiduamasakepemimpinan. Kepemimpinan pertama SKB dipegang oleh Bang Haden dari komunitas Sedekah Harian. Sedangkan saat ini kepemimpinan dipegang oleh Bang Jamal dari komunitas Pejuang Subuh. Sinergi Komunitas Bekasi bertujuan menjembatani kepentingan tiap-tiap komunitas muslim untuk saling membantu dalam mengemban amanah. Dimana sinergi ini menggalang pemuda muslim Bekasi untuk memberikan kontribusinya kepada masyarakat kota Bekasi (MGI, 2015).

Tujuan dari keberadaan SKB ialah sebagai wadah sinergi dari komunitas didalamnya. Sehingga setiap komunitas dapat membantu komunitas lainnya dalam menyelenggarakan suatu kegiatan. Dengan kata lain tiap komunitas muslim di Bekasi dapat saling memberikan dukungan satu sama lain (support).

\section{Pembahasan \\ Latar Belakang GEMAR Bekasi}

Gerakan Menutup Aurat (GEMAR) Bekasi merupakan gerakan yang ingin membumikan atau mengkampanyekan penggunaan hijab syar'i di Bekasi. Sebenarnya Gerakan Menutup Aurat (GEMAR) merupakan kampanye yang diselenggarakan oleh komunitas Peduli Jilbab. Namun GEMAR Bekasi bukanlah bagian dari GEMAR Nasional yang diusung oleh Peduli Jilbab. GEMAR Bekasi merupakan kampanye yang diselenggarakan oleh 22 komunitas Bekasi (pemuda Bekasi) dibawah naungan Sinergi Komunitas Bekasi (SKB).

Gerakan Menutup Aurat (GEMAR) Bekasi merupakan upaya penyadaran kepada perempuan muslim (muslimah) untuk menutup aurat berdasarkan ketentuan Al Qur'an. Selain itu, GEMAR Bekasi juga merupakan upaya dalam melawan budaya asing dan meningkatkan nilai spiritual umat muslim di Bekasi. Apalagi saat ini gempuran berbagai media sosial dan internet telah banyak membuat umat muslim jauh dari nilai-nilai islami. Lebih lanjut gerakan ini bertujuan untuk mengajak para muslimah di 
Bekasi agar memakai jilbab yang sesuai dengan ketentuan syar'i.

GEMAR Bekasi merupakan sebuah kampanye sosial atau dalam istilah Kotler disebut juga sebagai social change campaigns. Kampanye ini termasuk kampanye sosial karena kampanye ini memiliki tujuan yang berdimensi perubahan sosial yaitu meningkatkan nilai religiusitas wanita muslim Bekasi, melalui penggunaan hijab syar'i. Hal ini sejalan dengan UU No.40 tahun 2009 pasal 17 poin pertama bahwa peran aktif pemuda sebagai kekuatan moral diwujudkan salah satunya dengan: Memperkuat iman dan takwa serta ketahanan mental spiritual.

Kemudian poin kedua, peran aktif pemuda sebagai kontrol sosial diwujudkan salah satunya dengan: Membangkitkan sikap kritis terhadap lingkungan dan penegakan hukum. Dari dua poin tersebut menunjukkan bahwa sebagai agen perubahan pemuda memiliki peran kepedulian terhadap lingkungan hidup dan masyarakat (sosial). Maka GEMAR Bekasi merupakan salah satu bagian usaha SKB dalam meningkatkan nilai spiritual musimah di Bekasi sekaligus bentuk kepedulian SKB terhadap lingkungan sosial umat muslim di Bekasi.

Salah satu tokoh teori fenomenologi Alfred Schutz, meletakkan hakikat manusia dalam pengalaman subjektif, terutama ketika mengambil tindakan dan mengambil sikap terhadap dunia kehidupan segari-hari, begitupula yang terjadi pada GEMAR Bekasi. Dalam upaya memahami suatu tindakan seseorang, Schutz mengusulkan unsur motives untuk menggambarkan hal tersebut. Menurut Schutz tindakan didasarkan pada dua fase yaitu motive yang merujuk pada masa depan (in-order-to motive) dan motive yang merujuk pada masa lalu (because-motive).

Meminjam pemikiran Schutz, maka inorder-to motive GEMAR Bekasi adalah untuk mengedukasi masyarakat Bekasi mengenai pakaian atau hijab syar'i. Serta bertujuan pada perubahan perilaku masa depan masyarakat Bekasi agar memakai hijab tak hanya sebatas fashion melainkan sesuai dengan ketentuan Al-Quran. Sedangkan because-motive adanya gerakan GEMARBekasiadalahkarenakomunitas Peduli Jilbab tak bisa turut mengadakan GEMAR di Bekasi. Sehingga tercipta sebuah kampanye GEMAR dengan identitas Bekasi yaitu GEMAR Bekasi.

Di sisi lain Scott dan Lyman menyebutkan bahwa istilah motives kurang pas dengan kajian sosiologi. Maka mereka menyebutnya sebagai accounts, yang juga terdiri atas dua dimensi, yaitu; permasalahan (excuses) dan pembenaran (justifications). Mengikuti pemikiran Scott dan Lyman, GEMAR Bekasi lahir dari dua hal mendasar yaitu permasalahan (excuses) yaitu Fenomena trend hijab yang kurang sesuai dengan ketentuan dalam Al-Quran. Serta pembenaran (justifications) dimana GEMAR Bekasi merupakan bentuk tanggung jawab Sinergi Komunitas Bekasi (SKB) sebagai generasi muda muslim Bekasi. Mereka ingin membawa perubahan kehidupan sosial masyarakat muslim Bekasi ke arah yang lebih baik.

\section{GEMAR Bekasi dalam Perspektif The Five Functional Stages Development}

GEMAR Bekasi membuat pelbagai perencanaan agar kampanye ini bisa berhasil. GEMAR Bekasi merancang kegiatan-kegiatan yang dapat menarik atensi masyarakat di CFD Bekasi sekaligus dapat menyampaikan pesan kampanye. Perencanaan strategi GEMAR Bekasi dapat dilihat dari tahapan kampanye dalam perspektif The Five Functional Stage Development. Menurut model kampanye ini terdapat lima tahapan yaitu:

Tahap Identifikasi: Tahap penciptaan identitas kampanye yang mudah dikenali masyarakat serta penciptaan pesan kampanye. Pada kampanye GEMAR Bekasi 2017 identitas yang ciptakan ialah Logo (di desain oleh Muslim Designer Community). Kemudian pesan kampanye yaitu pesan verbal ialah berupa slogan, yel-yel GEMAR Bekasi 2017. Pesan nonverbal berupa khimar, dan penggunaan warna hijau sebagai identitas gerakan ini. Terakhir merancang 
pelbagai kegiatan pada kampanye GEMAR Bekasi. Kegiatan pada kampanye GEMAR Bekasi ialah longmarch, orasi berbentuk public speaking yaitu pada sekmen inspiring muslimah yang diisi oelh Indah Dari, tutorial dan edukasi hijab syar'i, pembagian khimar gratis, cek kesehatan dan photobooth.

Tahap Legitimasi: Tahap pemberian dukungan kepada kampanye. Legitimasi diperlukan agar masyarakat dapat menganggap secara serius gagasan atau isu permasalahan yang disampaikan dalam kampanye. Kampanye GEMAR Bekasi telah mendapatkan legitimasi pertama dari 22 komunitas sebagai penyelenggara kegiatan ini. Banyaknya jumlah komunitas yang menyelenggarakan kampanye ini menunjukka bahwa banyak komunitas di Bekasi menganggap kampanye ini sebagai suatu hal yang penting. Legitimasi berikutnya di dapat dari dukungan kalangan Public figure, yaitu dari kalangan pemerintahan dan kalangan artis.

Tahap Partisipasi: Partisipasi nyata ditunjukkan oleh keterlibatan orang-orang dalam melaksanakan dan menyelenggarakan aksi yaitu panitia GEMAR Bekasi, para sponsor dan peserta kampanye (khalayak umum). Panitia dalam kampanye sosial ini terbagi kedalam dua kategori yaitu panitia inti GEMAR dan relawan GEMAR. Panitia inti merupakan perwakilan dari tiap-tiap komunitas (22 komunitas) yang bertugas merancang, melaksanakan dan memfasilitasi setiap kegiatan GEMAR Bekasi 2017 yang telah disusun dalam rundown acara.

Sedangkan relawan GEMAR merupakan panitia yang direkrut secara sukarela dari pelbagai komunitas yang tak terlibat menjadi panitia inti. Panitia relawan bertugas memakaikan hijab (tutorial) hijab syar'i serta memberikan edukasi kepada masyarakat mengenai pentingnya menutup aurat. Pada GEMAR Bekasi 2017 jumlah panitia inti ialah sebanyak 78 orang dan panitia relawan berjumlah puluh 50 orang. Maka total panitia yang terlibat kampanye ini adalah 128 orang. Dari jumlah panitia yang banyak menunjukkab bahwa GEMAR Bekasi memang ditargetkan untuk mencapai khalayak yang banyak (bersifat massal).

Tahap Penetrasi: Tahap penyebaran informasi mengenai kampanye sosial GEMAR Bekasi. Saluran media yang digunakan ada dua yaitu secara luring dan daring. Secara luring (offline) yaitu menggunakan media massa Radio Dakta. Informasi disebarkan melalui talkshow dalam salah satu siaran Radio Dakta. Dalam talkshow ini humas GEMAR Bekasi diwawancarai oleh penyiar terkait kegiatan GEMAR. Sedangkan secara daring (online) media yang digunakan adalah media massa online yang menjadi partnership. Media tersebut yaitu Ahadtimes.com, Line.berdakwah.net, ESQNews.com, publikjurnalistik.org, Bekasimedia. com dan Channelmuslim.com. Serta melalui media sosial Instagram, Facebook, dan Youtube.

Tahap Distribusi: Merupakan tahap pembuktian. Ketika kampanye GEMAR Bekasi telah dilaksanakan maka GEMAR Bekasi perlu melakukan pembuktian. Beberapa cara yang dilakukan GEMAR Bekasi antara lain : pengumpulan tanda tangan, membuat video testimoni, serta melakukan dokumentasi media massa yang menunjukkan bahwa acara ini berhasil (memiliki nilai berita positif).

Berdasarkan lima tahap pada model kampanye The Five Functional Development dapat dikatakan bahwa Gerakan Menutup Aurat (GEMAR) Bekasi dapat menimbulkan kesadaran beragama pada generasi muda Bekasi. Khususnya kesadaran kalangan muda perempuan untuk menutup aurat secara syar'i, bukan mengikuti mode.

\section{Khalayak GEMAR}

Berdasarkan temuan dilapangan menunjukkan bahwa GEMAR Bekasi mampu menghidupkan kembali kesadaran wanita muslim di Bekasi untuk mengenakan pakaian syariah atau syar'i. Stanley Deetz dalam Litllejohn (2009: 57) menyimpulkan ada tiga prinsip dasar (asumsi) fenomenologi. Pertama, pengetahuan ditemukan secara langsung dalam pengalaman sadar. Menurut informan $\mathrm{KN}$ (peserta GEMAR Bekasi 2017) GEMAR Bekasi 
mampu memberikan pelajaran dan motivasi yang dapat menambah keyakinan untuk mengenakan hijab atau jilbab yang sesuai dengan ketentuan Al-Quran.

"Menyenangkan sih, seru. Jadi samasama belajar bareng buat mulai hijrah secara kaffah. Kegiatan ini juga sangat bermanfaat, ya tadi menginsipirasi. Bagi kita yang masih bingung atau ragu untuk memakai hijab syar'i jadi bisa sharing pengalaman satu sama lain. Yah.. bagibagi motivasi juga. Hal yang didapat dari Gemar itu pelajaran dan motivasi siih, bisa nambahin keyakinan kalau memakai jilbab yang baik dan benar seperti ini loh. Karena melihat banyak peserta nya juga yang pakai jilbab panjang juga nambah pede. Banyak juga kok yang pakai hijab syari, yahhh jadi namabah motivasi sih." [KN, Hasil Wawancara, 21 Mei 2017]

Hal yang sama juga dituturkan oleh informan AP (peserta GEMAR Bekasi 2017)

"Ya jadi kan kalau ternyata jilbab itu wajib, bukan perkara kita udah siap atau belum menggunakannya tapi memang kewajiban. Terus juga memakainya memang ada aturannya seperti menutupi dada gak tembus pandang gitu kak." AP, Hasil Wawancara, 22 Mei 2017]

Berdasarkan pernyatan di atas maka dapat dikatakan bahwa GEMAR Bekasi mampu menimbulkan kesadaran dan meningkatkan pengetahuan mengenai hijab atau jilbab syar'i. Dari pengalaman mengikuti GEMAR Bekasi mereka dapat berbagi (sharing) dengan peserta lainnya mengenai jilbab syar'i. Hal ini juga menambah keinginan mereka untuk menggunakan jilbab syar'i (motivasi).

Asumsi kedua yaitu makna benda terdiri atas kekuatan benda dalam kehidupan seseorang. Maka untuk menimbulkan keinginan penggunaan jilbab syar'i, GEMAR Bekasi membagikan khimar yang syar'i kepada wanita muslim di Bekasi. GEMAR Bekasi berharap dengan memiliki khimar yang syar'i, lambat laun akan memicu wanita muslim untuk menggunkan jilbab syar'i di kehidupan sehariharinya. Asumsi ketiga yaitu bahasa merupakan kesadaran makna. Dalam hal ini perserta GEMAR Bekasi mendapatkan edukasi mengenai hijab atau jilbab syar'i dari panitia relawan GEMAR Bekasi. Dimana edukasi yang diberikan panitia merupakan bahasa verbal.

\section{Kesimpulan}

Strategi kampanye sosial Gerakan Menutup Aurat (GEMAR) Bekasi dalam perspektif model kampanye Five Functional Stages Development terdiri atas lima tahap, yaitu:

1. Tahap Identifikasi. Tahap penciptaan identitas dan pesan kampanye seperti logo, pesan kampanye baik pesan verbal berupa slogan, poster, dan yel-yel, dan pesan nonverbal berupa khimar (hijab) syar'i dan penggunaan warna identitas kampanye. Serta perencanaan pelbagai bentuk kegiatan pada kampanye GEMAR Bekasi 2017.

2. Tahap Legitimasi yaitu tahap pemberian dukungan kepada kampanye. Legitimasi diperlukan agar masyarakat dapat menganggap secara serius gagasan atau isu permasalahan yang disampaikan dalam kampanye. Pertama adanya dukungan dari dua puluh dua komunitas muda di Bekasi. Kedua, dukungan pemerintah dengan hadirnya Wakil Walikota Bekasi, perwakilan Departemen Agama Bekasi dan Baznas Bekasi, serta dukungan dari kalangan artis yaitu Indah dari Caesar.

3. Tahap Partisipasi. Partisipasi nyata ditunjukkan oleh keterlibatan orang-orang dalam melaksanakan dan menyelenggarakan aksi yaitu 128 panitia GEMAR dari pelbagai komunitas muda muslim di Bekasi, para sponsor dan peserta kampanye (khalayak umum).

4. Tahap Penetrasi yaitu tahap penyebaran informasi mengenai kampanye sosial 
GEMAR Bekasi. Ada dua saluran yang dipilih untuk menyebarkan informasi, yakni secara luring dan daring. Secara luring (offline) yaitu melalui Radio Dakta. Sedangkan daring (online) yaitu media massa online (Ahadtimes.com, Line.berdakwah. net, ESQ-News.com, publikjurnalistik.org, Bekasimedia.com dan Channelmuslim.com) dan media sosial yaitu facebook, instagram dan youtube.

5. Tahap Distribusi (pembuktian).Tahap distribusi bisa disebut juga sebagai tahap pembuktian. Dalam upaya membuktikan bahwa kampanye ini mendapat respon positif dari masyarakat ada beberapa langkah yang ditempuh : pengumpulan tanda-tangan (petisi dukungan) khalayak, video testimoni, serta dokumentasi pemberitaan massa online yang menunjukkan respon positif.

Dengan demikian maka kampanye GEMAR Bekasi telah memenuhi kelima tahapan model kampanye Five Functional Stages Development. Artinya kampanye GEMAR Bekasi telah berjalan dengan baik. Selain itu komentar dan pemberitaan di media massa online juga menunjukkan respon yang positif dari masyarakat Bekasi terhadap kampanye ini.

Berdasarkan lima tahap pada model kampanye The Five Functional Development dapat dikatakan bahwa Gerakan Menutup Aurat (GEMAR) Bekasi dapat menimbulkan kesadaran beragama pada generasi muda Bekasi. Khususnya kesadaran kalangan muda perempuan untuk menutup aurat secara syar'i, bukan mengikuti mode.

\section{Daftar Pustaka}

Awalina, Kamalia Rizqi. 2015. Manajemen Komunikasi Kampanye Jilnan Syar'I (Studi Kasus Manajemen Komunikasi pada Kampanye Yuk Berjilbab Syar'I Peduli Jilbab dalam Mengampanyekan Pemakaian Jilbab Syar'i). Skripsi. Program studi Ilmu Komunikasi. Universitas Gadjah Mada. Yogyakarta. Dewi, Savirah Maya. 2014. Anjuran Menutup
Aurat Dalam Film Kejarlah Jodoh Kau Ku Tangkap. Jurusan Komunikasi Islam. Skripsi. Fakultas Dakwah dan Komunikasi. Universitas Islam Negeri Sunan Kalijaga Yogyakarta. Firmansyah, Irman. 2016. Sindonews.com. Adu Kreatif Komunitas di HAKABE 2016. Dalam:https://lifestyle. sindonews.com/read/1143840/166/ a d u - kreatif - k o m un it a s - d i hakabe-2016-1475320786. unduh tanggal 17 Maret 2017. Janmohamed, Shelina. 2016. Generation M: Young Muslims Changing The World. New York: I.B. Tauris \& Co.Ltd. London. Kamus Besar Bahasa Indonesia (Online). Dalam http://kbbi.web.id/. Diunduh tanggal 15 Mei 2017. Kuswarno, Engkus. 2009. Metode Penelitian Komunikasi Fenomenologi: Konsepsi, Pedoman dam Contoh Penelitianya. Bandung: Widya Padjajaran. Littlejohn, Stephen W \& Karen A. Foss. 2009. Teori Komunikasi(theories of human communication). Edisi 9. Jakarta: Salemba Humanika.

\section{Internet}

Lestari, Dwi. 2014. Peduli Jilbab. Dalam: http:// www.dwibcc.org/2014/01/peduli-jilbab.html. Di unduh tanggal 17 April 2017.

MG1. 2015. Lebih Dekat Dengan Sinergi Komunitas Bekasi. Dalam: http://gobekasi. pojoksatu.id/2015/11/08/lebih-dekat-dengansinergi-komunitas-bekasi/. Diunduh tanggal 5 April 2017.

Monica, Laura Christina Luzar. 2011. Efek Warna Dalam Dunia Desain dan Periklanan. Jurusan Desain Komunikasi Visual. Universitas Binus. Jurnal Humaniora Vol.2 No.2

Official. 2016. Bekasikota.bps.go.id. Jumlah Kependudukan Dalam:https:// bekasikota.bps.go.id/S ubjek/view/ id/12\#subjekViewTab3|accordion-daftar- 
subjek1. Di unduh tanggal 17 Maret 2017.

Putro, Aditiyo Dwi. 2015. Kampanye Sosial Membangun Kesadaran Beretika Komunikasi Di Sosial Media Pada Masyarakat Dewasa Dini Bandung. Jurnal online. Prodi Komunikasi Visual, Fakultas Industri Kreatif, Universitas Telkom. Dalam: http://openlibrary.telkomuniversity. ac.id. Di unduh tanggal 25 Juni 2017.

RWA/HIA. 2017. Chanelmuslim.com. Gerakan Menutup Aurat Ramaikan CFD Bekasi. Dalam :https://www.chanelmuslim.com/lifestyle/ komunitas/gerakan-menutup- ramaikan-cfdbekasi/20044/. Di unduh tanggal 17 Maret 2017.

Satries, Wahyu Ishardino. 2009. Peran Serta Pemuda Dalam Pembangunan Masyarakat. Jurnal Madani Edisi I/Mei 2009.

Syamsuddin, Ahmad. 2015. Sebenar-benarnya Valentine Day. Makalah Islami online. Jakarta: Kementerian Agama (Kemenag). Dalam:http:// simbi.kemenag.go.id/pustaka/index.php/ pustaka-islami/makalah-islami?start $=5$.Diunduh tanggal 2 Juni 2017.

Takariawan, Cahyadi, dkk. 2003. Keakhwatan 2: Bersama Tarbiyah Mempersiapkan Akhawat Menjadi Daiyah. Solo: Era Intermedia.

Tim. 2012. Muslimdaily.net. Lawan Hari Valentine Dengan Gerakan Menutup Auarat. Dalam:http://www.muslimdaily.net/berita/ nasional/lawan-hari-valentine-dengan-gerakanmenutup-aurat.html.Di unduh tanggal $1 \mathrm{Mei}$ 2017.
Undang-undang 40 Tahun 2009 (Online). Dalam http://www.dpr.go.id/dokjdih/document/uu/ UU_2009_40.pdf. Diunduh tanggal 26 April 2017.

Venus, Antar. 2004. Manajemen Kampanye: Panduan Teoritis dan Praktis dalam Mengefektifkan Kampanye Komunikasi. Bandung: Simbiosa Rekatama Media.

Wallis, Claudia. 2006. Content.time.com. Time Magazine: Generatiof of $\mathrm{Me} \mathrm{Me} \mathrm{Me}$. Dalam: http:/content.time.com/time/magazine/ article/0,9171,1174696,00.html. Di unduh tanggal 4 April 2017.

Widorini, Wahyu Yuliastuti. 2014. Studi DeskriptifKualitatiftentang Strategi Komunikasi Earth Hour dalam Kampanye Gaya Hidup Ramah Lingkungan di Kota Solo Tahun 2013. Skripsi. Program studi Ilmu Komunikasi. FISIP. Universitas Sebelas Maret. Surakarta.

Yani, Ahmad. 2014. Ikadi.or.id. Say No To Valentine's Day. Dalam: http://ikadi.or.id/artikel/ kajian/1055-say-no-to-valentines-day.html. Diunduh tanggal 3 Juni 2017. 